\title{
The Evolution of Family Entrepreneurship in Poland: Main Findings Based on Surveys and Interviews from 2009-2018
}

\author{
Andrzej Marjański, Łukasz Sułkowski
}

\begin{abstract}
A B S T R A C T
Objective: The article deals with the issue of family entrepreneurship, which plays an increasingly important role in the Polish economy. The aim of the article is to discuss the phenomenon of family entrepreneurship in Poland in market economy and to explore the evolution of family businesses.

Research Design \& Methods: The article is based on the review of the literature on the subject, its critical analysis and the results of empirical research conducted in this field by the authors in the years 2009-2018.

Findings: In their development, family businesses need to take into account coping with the principles and practices of market economy and internationalisation processes, as well as problems related to family and business relationships that are specific only to them and multi-generational perspective of functioning. Being successful requires a development strategy thanks to which the businesses build their own brand, improve management processes, introduce innovations and adapt their market behaviour.
\end{abstract}

Implications \& Recommendations: Understanding the specificity of family entrepreneurship requires learning their essence and criteria for distinguishing these entities from other enterprises. The key factor is the duality of relations between the family and the business it runs.

Contribution \& Value Added: The originality of this work lies in cross-years comparisons of empirical research conducted by the same researches in the field of family entrepreneurship.

Article type: research article

Keywords: family firms; strategy; entrepreneurship; research methods

JEL codes: L26

Received: 15 July 2018

Revised: 2 January 2019

Accepted: 7 January 2019

\section{Suggested citation:}

Marjański, A., \& Sułkowski, Ł. (2019). The Evolution of Family Entrepreneurship in Poland: Main Findings Based on Surveys and Interviews from 2009-2018. Entrepreneurial Business and Economics Review, 7(1), 95-116. https://doi.org/10.15678/EBER.2019.070106 


\section{INTRODUCTION}

The article focuses on the issue of family entrepreneurship and the process of its evolution taking place in the process of development of family businesses ${ }^{1}$, which constitute a significant group of economic entities in the Polish economy. The development of family firms is one of the effects of the free market economy in Poland after 1989 and opportunities for the development of private entrepreneurship (Bednarz et al., 2017). It is also an example showcasing that many business ventures are created as a result of activities undertaken by the members of the family with the use of its human, material and financial resources. In the development of entrepreneurship research it is important to take into account the whole diversity and specificity of the organisations, which are the basic elements of collective cooperation in modern societies (Aldrich \& Ruef, 2006).

One of the key areas of entrepreneurship is family entrepreneurship, which is an interesting example of dual relationships between the family and the business run by the family. The specificity of these relationships means that the functioning of such entities is in many areas different than in other firms, because in the process of managing a family business, in addition to business arguments, the interests of the family as a whole and its members are always taken into account. Family entrepreneurship is an important element of economic life, and family businesses are perceived as a spirit of entrepreneurship and innovation, and constitute a key element of market economies in most countries, including Poland. Among family businesses, there are micro- and small enterprises (small and medium-sized enterprises, SMEs), as well as large economic entities (large enterprises, LEs) operating on international markets. Estimates suggest that two-thirds of companies around the world are family-owned, family-controlled and family-managed. They provide 60 to $90 \%$ of global GDP (IFERA, 2003) and are important sources for creating stable jobs at the same time (Ibrahim et al., 2008).

In Poland, dynamic development of family firms was possible thanks to the systemic changes initiated in 1989, which enabled, among others, free development of entrepreneurship (Sułkowski \& Marjański, 2015; Zygmunt, 2018). The first representative survey of Polish family businesses conducted in 2009 confirmed that they account for about $80 \%$ of all small and medium-sized enterprises (Sułkowski et al., 2009) and the development of family enterprises in Poland is an example of significant changes in the economy and is a symbol Poland's economic success.

Polish family firms participate in dynamic changes taking place on the market and have to face new challenges affecting their functioning and the shape of their strategy. In the aspect of progressing globalisation processes, strategic orientation directed at taking innovative actions that will enable the company to adapt to the requirements of the market economy, European integration and internationalisation are important (Wach, 2017; Rogalska, 2018; Ivanová, 2017; Korcsmáros \& Šimova, 2018). At the same time, they are also subject to processes of changes resulting from their family nature connected, for example, with the processes of succession.

\footnotetext{
${ }^{1}$ The terms 'family business', 'family firm' and especially popular in continental Europe 'family enterprise' will be used interchangeably in the article.
} 
The changes taking place in the development processes of Polish family firms have created a number of challenges related to the management of these entities. They have their consequences in the following areas:

- the functioning and development of Polish family businesses takes place in the conditions of low social capital in the Polish society and the threat of 'amoral' familism;

- there appear challenges related to succession, because generational change has become a permanent element in the functioning of family enterprises;

- the complexity of managing family businesses increases due to increasing competition and progressing globalisation and European integration.

Dominating the landscape of most economies by family businesses also creates the need to expand the scope of research that provides knowledge about the areas of management of family businesses (Chrisman, Chua, \& Steier, 2003a). Noticing the significance and separateness of this type of business entities has led researchers to pay attention to family firms as a unique area of research and interest (Sharma, 2004) due to the fact that the family is a critical variable that allows to understand the essence of these businesses and their high economic and social importance (Astrachan, 2003). Thus, they arouse more and more interest in theoretical and empirical research (Cristiano, 2017). In family entrepreneurship, attention is paid to the uniqueness of these entities, resulting from the combination of the need to realise profits with the longterm perspective of building the enterprise's value and maintaining its functioning despite changing generations of the owners. Family is the sum of positive associations, hence family enterprises are becoming more and more popular. This is due to the fact that it is the family that carries universal values that are not subject to fashions or changing marketing trends. In families running a business for generations, business traditions naturally combine with a system of values, among which respect for work and for the other person is in the foreground.

Despite the existence of many different positions and orientations in the scientific discourse, ranging from the question of distinguishing and defining, researchers agree that in this type of entities members of the same family have the ownership and influence on their functioning and strategy (Astrachan \& Shanker, 2003). Researchers agree that family businesses operate on the border between two qualitatively different social institutions - family and business (Lansberg, 1983) and the differences between family and non-family entities result from the fact that these two institutions exist for completely different purposes. The family is to care for family members and the main goal of business is to provide goods and services for economic benefits (Simon, 2009). In a family-owned firm, these two systems overlap and form a single business system that, due to family involvement, differs from a business that is not controlled by the family.

The aim of the article is to discuss the phenomenon of family entrepreneurship in Poland in the market economy and to explore the process of their evolution.

The article consists of three main parts. First, the findings of prior studies are summarised, taking into account its three main themes (nature, specific character and the Polish realities for family firm research). Second, reference was made to the methodological conditions related to conducting studies on family entities in the modern economy. Third, the academic discussion of prior research is presented. 


\section{LITERATURE REVIEW OF PRIOR STUDIES}

\section{The Nature of the Research Area of Family Entrepreneurship}

At present, the dynamic development of entrepreneurship research is visible. The subject of entrepreneurship is taken up both by management sciences, where it gained the status of a separate sub-discipline, as well as by other disciplines of social sciences (e.g. sociology, psychology, economics) (Szaban \& Skrzek-Lubasińska, 2018). The phenomenon of entrepreneurship is extremely diverse and is perceived in different contexts. Among various types of entrepreneurship, the literature on the subject is considered a separate kind of family entrepreneurship. In scientific research attention is more and more often paid to the uniqueness of family businesses, and their common feature is the implementation of economic results with the multi-generational perspective of building the value of the enterprise. It is possible thanks to the family and its commitment to running the business, and which is a carrier of universal values that are not subject to fashions or changing trends. The combination of family and business components translates into the theoretical complexity of research issues and implies the need to apply an appropriate methodological approach in empirical research (Wilson et al., 2014).

In the academic area, the issue of family entrepreneurship has been present since the early 1980s, with the appearance of the special edition of the Organisation Dynamics journal and as indicated by Astrachan (2003) it was the beginning of the quest for a new research area - family entrepreneurship. Before the 1980s, the term 'family business' appeared occasionally presenting scanty empirical research and most articles were of a theoretical nature. In 1988, the first scientific journal Family Business Review (FBR) devoted to studies and research on family enterprises was published (Astrachan, 2003). However, it was only in the 1990s that family business research began to constitute a separate area of scientific research (Bird, Welsch, Astrachan, \& Pistrui, 2002). The research area of family entrepreneurship is multidisciplinary and distinguishes itself by focusing on a number of paradoxes that create family involvement in running a business (Sharma et al., 2014), located at the interface between different areas and creates the opportunity to conduct research combining economic and management, sociological psychological issues and many others and the unique nature of the ownership and organisation of family businesses gives the opportunity to ask many interesting research questions (Leszczewska, 2017).

In Poland, the interest in this issue dates back to the1990s. The first surveys of Polish businesses were conducted. The leading researchers in Poland include among others Krzysztof Safin, Alicja Winnicka-Popczyk, Wojciech Popczyk, Ewa Więcek-Janka, Łukasz Sułkowski, Andrzej Marjański, Jacek Lipiec, Nelly Daszkiewicz and Krzysztof Wach. The first representative surveys of Polish family firms were conducted in 2009. Currently, research on family entrepreneurship is regularly conducted in several research centres and is increasingly reflected in the Polish literature on the subject. However, there is a clear need to reduce the cognitive and empirical gap between domestic and foreign knowledge in the field of family entrepreneurship, especially in the field of broad and systematic empirical research (Jeżak, 2014, pp. 9-10).

In research on family enterprises, it seems crucial to strive to understand their specificity and characteristics that distinguish them from non-family enterprises, so that a full picture of these entities can be obtained. One should strive to define rules and distinguish 
the specificity of a family business and indicate good practices that can be used by managers in the process of enterprise development and the reference to long-term success in the business and family dimension (Więcek-Janka, Contreras Loera, Kijewska, \& Tirado, 2016). Many researchers indicate that the relationships between the family system and the enterprise system make the processes of managing and building strategies different from those occurring in non-family companies (Harris, Martinez, \& Ward, 1994).

In the research undertaken, it is always necessary to address issues related to the particular involvement of the family in running the business (Sharma, Christman, \& Gersick, 2012) and how family relations are combined in the business dimension of running the company (Chrisman et al., 2003). Many researchers, including Chrisman, Chua and Sharma (2003a) indicate that it is necessary to apply the theory of management and economics in studies on the essence of family enterprises because all key issues occurring in the theory of the firm, such as (i) why the enterprise exists, (ii) what its nature is, (iii) what the goals its activities are and (iv) where the boundaries of firms are refer also to family businesses.

\section{A Specific Character of Family Entrepreneurship}

Family entrepreneurship is undoubtedly characterised by a strong relationship with one or several families that determine the functioning and development directions of individual entities. In most cases, these are small or medium-sized enterprises, which is an important determinant affecting the shape of their development process (Cristiano, 2017). But there are also large family businesses that have increased their size in the process of their development. The creation of different types of family enterprises is also observed. The common feature of family businesses is the multifaceted connection between business and the owning family. Astrachan (2003) even indicates that the family is a critical variable that allows to understand the essence of family business.

Family entrepreneurship is the oldest form of entrepreneurship, the functioning of which is observed in all cultures and historical periods (Gasson et al., 1988). Also today, family businesses are the most numerous and natural form of doing business all over the world and include both small and medium-sized enterprises, as well as large family-controlled economic entities. Key factors that distinguish family businesses are: family ownership structure, family members' participation in management and participation of more than one generation in the functioning of the entity (Handler, 1989).

The family factor is essential for the functioning and development of the family business and for shaping its resources, which are valuable, rare and without substitutes. At the same time, the resources of the family business are difficult to imitate (Barney, 1991). Human capital, family social capital and material and financial capital are of key importance. In a family enterprise, intangible assets play a special role, which can be a source of sustainable competitive advantages and their impact can create synergies (Sirmon \& Hitt, 2003). Knowledge-based resources and the entity's reputation are important for the family firm (Hadryś, 2018).

Family enterprises are distinguished by the dual impact of family and enterprise subsystems. This situation determines the way entities are run as well as the directions of their development (Moss, Payne, \& Moore, 2014), which means that decisions and actions also reflect the unseen assumptions about the consistency of family participation in running the business and the willingness to hand the business to the next generation (Lumpkin \& Brigham, 2011; Petrů \& Havlíček, 2017). Such an option makes it possible to 
create a strategic orientation enabling the creation of a competitive advantage expressed in the long-term development of basic competences as well as the development of organisational culture and relations with stakeholders (Miller \& Le Breton-Miller, 2006). In a family business the strategic orientation must reflect the concern of the owner family to preserve the intergenerational continuity of the entity and it is also based on social and emotional factors and is undoubtedly one of the key factors determining the development of the entity (Gómez-Mejía et al., 2007; Kot et al., 2016). In shaping the strategic orientation, the key role is played by the company's stakeholders who are members of the owner's family and management. On the other hand, the shape of the strategic orientation of a family enterprise is the resultant of business and family factors as well as the preferences of managers and employees (Safin, 2014).

Family businesses are economic entities that on the one hand must have the characteristics attributed to the enterprise in general and, on the other hand, stand out with a number of features that allow them to be considered family businesses. In the research area the specificity resulting from the family nature of business is emphasised, which manifests itself in the long-term optics of functioning, parallel implementation of business goals and family goals, in the case of small and medium-sized entities, close connection with the local environment and a specific approach to human resources management. The specificity of the family business stems from the constant interpenetration of the business and family spheres. This constellation makes the behaviour of family enterprises different from the one in which the family factor is absent or marginal. An example of such a difference is among others intergenerational succession. The difference covers both the area of current activities, as well as strategic orientations and behaviours, as well as shaping their competitive advantage (Hoy, 2014). The dimension of the specifics causes that family enterprises are not only entities with a specific form of ownership, but constitute a separate type of enterprise (Safin, 2014).

The functioning of family businesses is subject to evolution, which is influenced by both changing operating conditions and internal factors. It is increasingly recognized that due to the introduction of new solutions in the area of management, there are basically no limits to the development of the firm. Therefore, one of the fundamental objectives of research into family enterprises is to learn how they differ from non-family enterprises, to explore benefits and challenges related to family ownership and family involvement in the company (Binz-Astrakhan et al., 2018) and to seek determinants shaping the success of these enterprises and to formulate, on this basis, postulates regarding directions of development and improvement of management methods in the dynamically changing reality. Together with the development of research on family entrepreneurship, the dynamisation of interdisciplinary research and the convergence of individual scientific disciplines are visible. But despite the progress in research, the issue of learning their nature and principles of functioning is one of the basic research challenges.

\section{Characteristics of Family Entrepreneurship in Poland}

It can be seen, from the nearly 30 years of experience of the functioning of the market economy, that family entrepreneurship is an important element of the Polish economy. It can be concluded that the intensive development of family enterprises illustrates the phenomenon of entrepreneurship of the Poles and is one of the key successes of the Polish economy. The majority of Polish family enterprises are included in the SME sector and 
their significance results from both a significant share in generating GDP and jobs, which affects the stability of economic and social development. It is also important to refer to the specific features of family businesses, namely the ethical nature of the activity, the construction of community and loyalty and the development of teamwork skills. A family enterprise is also an example of combining work and family life.

The formation of many new family businesses in the 1990s was the result of the development of the free market and the creation of competition. A number of factors contributed to this, including:

- A wave of small business development in the first half of the 1990s. It resulted in the creation of new business entities in the years 1990-2000.

- A sudden increase in unemployment in the years 1990-1995 forcing entire families to take on new challenges in the form of starting a business.

- Very high cost of raising capital associated with high inflation and fiscal policy during the economic reforms (1990-1999) favouring family accumulation and allocation of capital needed to start a new business (McMilian \& Woodruff, 2003; Bilan at al., 2018).

- The key position of the family in studies of the hierarchy of social values in Poland that has been sustained over many recent decades (Nowak, 1981).

- A low and systematically decreasing level of social capital and trust strengthening the family relationship in the creation of new business ventures (Czapiński \& Panek, 2011).

- Cultural syndromes: 'social vacuum' and 'amoral familism' resulting from historical reasons (lack of Polish independence for over two centuries, lack of civil society and democratic institutions), which strengthen the position of the family in comparison with other social groups (Sztompka, 1998).

As a result, many family enterprises, which currently constitute an extremely valuable element of the Polish economy, were created. They were founded by those who saw the possibilities of the new economic system and started working on their own. Changes in the behaviour of individuals and social groups in the perception of the role of entrepreneur and the importance of entrepreneurship in social reception were also extremely important. Family businesses were also started to be pointed out as places where work and family life are combined and teamwork skills and a sense of community and loyalty are developed. Currently, succession is already one of the key challenges for family businesses and about one quarter of them is undergoing a generational change The research confirms that young people who have been brought up in a family business environment have more developed entrepreneurial attitudes than people who do not have such experiences (Wach, 2015).

It was noticed that entrepreneurs are important initiators of social and economic changes and constitute a distinctive social group that is characterised by a high degree of independent thinking and an open attitude towards undertaking new ventures. In 1995, there were over 2 million small and medium-sized enterprises (SMEs) in Poland, employing about $60 \%$ of professionally active citizens, providing nearly half of GDP (Ministry, 1995). The implementation of the transformation programme of the Polish economy has enabled the construction of a thriving sector of private enterprises and introduced a number of legal and institutional reforms that led to Poland's membership in the European Union in 2004 (Ubrežiová, Wach, \& Horváthová, 2018). It should be recognized that the accession to the European Union was an important factor determining the development of the Polish economy and the evolution of family enterprises. 
Currently, the Polish economy is, in many areas, more and more comparable with the economies of countries with a stable market economy, which is visible in the inflation indicators, interest rates and stabilisation of the labour market. Macroeconomic conditions affecting the functioning and the level of enterprise development are gradually improving. The share of the enterprise sector in the generation of gross domestic product is approx. $75 \%$, of which SMEs generate $48.5 \%$, while microenterprises account for $29.7 \%$. Eurostat data show that the share of the SME sector in Poland is at the same level as the average for the European Union countries and the enterprise sector is the main factor in the development of the Polish economy (PARP, 2014). A survey of Polish family businesses carried out in 2009 confirmed that they constitute approximately $78 \%$ of all small and medium-sized enterprises (Sułkowski et al., 2009). Taking into account the results of the report of the Polish Agency for Enterprise Development, it can be stated that Polish small and medium-sized family enterprises amount to almost 1345 thousand employers giving jobs to over 4546 thousand employees and contributing to the creation of over $37 \%$ of GDP. These figures indicate that the population of family enterprises in the Polish economy is comparable with other countries with a well-established market economy (PARP, 2014).

\section{MATERIAL AND METHODS}

The article is based on a review of the subject literature, its critical analysis and the results of research conducted in this field by the authors. It also indicates the methodological determinants for studying family firms. In order to achieve the goal of the article, the essence of the research area of family entrepreneurship was discussed and the characteristics of family enterprises in Poland was made. The results of the research carried out by the authors in the years 2009-2010, 2014-2016 and 2017-2018 were also referred to and the conclusions were formulated. The research samples used are as follows:

1. $n=1280$ family and non-family entities in the years 2009-2010;

2. $n=10$ family firms in the years 2014-2016;

3. $n=20$ family firms in the years 2017-2018.

The quantitative approach (a survey) was applied in 2009-2010, while the qualitative approach (in-depth interviews and case studies) was applied in the next two research projects (1914-2016 and 2017-2018). More details will be discussed in the next part of this article.

The research area of family firms is a difficult and complex challenge and the methodology of research is rarely the subject of scientific reflection. This is due to the fact that the concept of a family enterprise is interdisciplinary and is an area of interest for many fields of science. This causes that, in many cases, it is a poorly explored area or treated as marginal for a given discipline. Also the differences in the criteria distinguished and categorised by a family business cause the need to reconcile the concept of a family business in a research process. As part of various research programmes, we have collected a number of observations and experiences regarding the use of various research methods and related methodological problems arising in the process of getting to know family businesses.

Numerous methods of quantitative and qualitative research are used in the research into family enterprises in the world. The quantitative research methodology, although 
representative and leading to generalisations, does not always allow for a deeper understanding of complex social processes taking place in family enterprises. In contrast, qualitative methods are particularly useful for examining the problems of family businesses due to their specific connection of business (economic) relationships with family (emotional, personal and private). It seems reasonable to apply qualitative methods to research on the sphere of identity, culture, values and the relationship between family and business. As the experience of many researchers shows, qualitative methods allow for more effective obtaining of reliable data on 'sensitive' topics in comparison with quantitative methods (Sułkowski \& Marjański, 2014).

Conducting research in family enterprises has some restrictions similar to those related to the research of business entities based on primary sources:

- it is difficult to reach the examined subject and make him/her participate in the study;

- much of the information is deliberately hidden because it is considered a source of competitive advantage, know-how or includes sensitive family issues;

- the quality of the acquired research material is highly diversified due to the different level of involvement of the subject of the study;

- an important problem is to achieve representativeness due to refusals to participate in the study;

- problems are caused by sampling because there are no reliable selection procedures that can identify family businesses.

In addition, in studies of family businesses, especially small ones, there are problems specific to this type of entities related to the limited size of the enterprise and a low level of formalisation. There is little standardised documentary material allowing to develop research based on primary sources. It is difficult to conduct research based on representative samples, because there are no sampling frames covering only family businesses. In the study, it is necessary to filter from a sample of small companies or from the SME sector, based on the definition of familism.

In this area of family businesses, there are no identical criteria and there is considerable diversity and multiplicity of definitions, based on various criteria such as: selfdetermination as a family business, planned or completed family succession, ownership and management of family members over the company. In practice, it is often difficult to check the existence of other criteria apart from self-determination. Many researchers and our experience point to a particularly sensitive area of research, which is the overlapping relationship between the company and the owner's family. For this reason, the family and nepotistic relationships and practices are usually camouflaged as well as the flows of resources between the company and the family.

One should take into account the special emotional attitude of family members owning the controlled economic entity, which often causes a very subjective and idealised description of experiences related to a family business. And it is possible to reach the key areas for the functioning of the organisation: social processes, identity, culture, values and norms related to the family character of the entity only by using in-depth methods.

Social research on the organisation side is particularly methodologically demanding and requires methodological pluralism, which gives the possibility of combining quantitative and qualitative methods and triangulation of methods, which is more often associated with qualitative methodology (Sułkowski \& Marjański, 2014a). A diagnosis of these key 
research problems indicates that qualitative research that allows for a deeper, individual understanding of the complexity of the phenomena studied may be particularly valuable cognitively, which is confirmed by the experiments of the authors of this publication. We mainly mean methods of organisational anthropology, such as: in-depth interviews, participant observation, autoethnography and case studies.

Qualitative methods are useful for researching the problems of small family businesses, in particular problems related to the sphere of identity, culture, values and the relationship between family and business. Qualitative methods allow for more effective acquisition of reliable data on 'sensitive' topics in comparison with quantitative methods. It is equally important to provide information on complex social processes that are explored better using open methods. However, one should be aware that it is not free of restrictions and by definition generalisations and theorising create problems. The results of research are subject to considerable subjectivism, which transforms into inter-subjectivity through the use of various methods and perspectives.

In family business research, methodological pluralism, which allows the creation of mixed research programmes, should be postulated. Combining quantitative and qualitative methods in one research programme can provide important but not always commensurate results. It is also possible to indicate the need for methodological triangulation and thus the use of various complementary methods and research techniques that will allow to describe the examined family company in its entire complexity.

\section{EMPIRICAL RESULTS AND DISCUSSION}

We have been conducting research for over a dozen years to understand the specificity of family businesses, including three main periods (as mentioned before):

1. 2009-2010 (e.g. Sułkowski et al., 2009; Sułkowski \& Marjański, 2011);

2. 2014-2016 (e.g. Sułkowski \& Marjański, 2015; Marjański \& Staniszewska, 2017; Sułkowski \& Marjański, 2018);

3. 2017-2018 (e.g. Marjański et al., 2018).

\section{Quantitative and Qualitative Survey 2009-2010}

As part of the implementation of various research programmes we have collected many observations. We were members of the team implementing the first representative survey of family enterprises in Poland which was carried out on a sample of 1280 entities. The 'Family Businesses and the Polish Economy - Opportunities and Challenges' research programme was implemented in 2009-2010 at the request of the Polish Agency for Enterprise Development (PARP). This issue was taken due to the fact that family businesses were considered a valuable element of the entrepreneurial sector whose development should be supported as in many European countries. Until then, no activities were addressed to this group of companies. The adoption of a policy to support the development of family businesses required research to be able to characterise and examine their specificity and to identify their needs and problems in their operations. Moreover, the aim of the project was to fill the existing information gap within the scope of providing reliable data on the share of family enterprises in the SME sector and their characteristics against non-family entities (Sułkowski et al., 2009). 
Due to the complexity and interdisciplinary nature of research issues and due to the fact that until now the issue of family entrepreneurship was not the subject of representative research in Poland, it was necessary to ensure that demands such as the following were met:

- application of qualitative and quantitative methods;

- ensuring a multi-stage research procedure;

- the need for methodological triangulation and data triangulation;

- participation in the study of various actors, both owners and managers and employees of the lower level, including those from outside the owner's family;

- including both representatives of family enterprises as well as external experts from scientific communities, business organisations, consulting and training companies and employees in the study.

Due to the lack of reliable data on the participation of family businesses in the SME sector and their structure, it was necessary to apply a multi-stage research procedure. This procedure made it possible to reliably estimate the share of family businesses in the SME sector (including the share in GDP and the overall employment structure) and also gave an answer to all of the goals and research questions posed. Thanks to the use of quantitative methods, it was possible to estimate the size of the population of small and medium family enterprises in Poland. However, a standardised interview or survey does not provide an image of informal family relationships that have a key impact on the functioning of the company.

On the other hand, thanks to qualitative methods, it was possible to obtain indepth knowledge on the relationship between constraints and family values and the functioning of the company. The search for family relationships is often located in the sphere of problems and sensitive questions that are associated with nepotism. Therefore, to investigate the impact of family ties on organisational strategy, structure and culture, human resource management and training needs, it was extremely important to apply both qualitative and quantitative methods.

Data from various sources were used in the research process and many research methods were used (including free interviews, questionnaire interviews). Qualitative data and hypotheses formulated on the basis of them were verified on the basis of quantitative data which was obtained on the basis of a representative sample, while quantitative data on key research issues was deepened in qualitative research. An important issue was to capture in the research both the owner's family and employees from outside the family. In order to maintain the objectivity of assessments for fear that family business managers may be too emotionally connected with the company, their statements as well as the statements of employees of family enterprises were confronted with the opinions of experts cooperating with family businesses on a daily basis.

The study found that family businesses in Poland in terms of structural features including the number of employees, the scope of activity, the volume of turnover and the scope of investment undertaken are not fundamentally different from non-family entities. The specificity of the surveyed entities was identified in the sphere of values, organisational culture, level of social trust, hierarchy of goals and strategy. It was also important to determine, irrespective of the type of activity conducted, that family enterprises have common features influencing the shaping of their system of values, identity, organisational culture and family social capital. An interesting observation was also the fact that they were exposed in various ways in the surveyed enterprises. 
It was established that the average Polish family firm is around 15 years old. In terms of some structural features, such as the size of the enterprise, the number of employees, the scale of operations, the volume of turnover or the scope of investment undertaken they are not in a fundamental way different from non-family businesses. There were also no significant differences in the perception of key barriers to the development of Polish entrepreneurship and expectations in relation to actions that should be taken to facilitate business operations. The analyses showed that the differences were more related to the size of the entity than to its family character. It can be assumed that this situation results from the fact that most of the surveyed enterprises were at an early stage of development, in which there were no problems related to family entrepreneurship such as: incorporation of new generations to work in the company, planning and conducting succession, or hiring external managers.

Essential differences indicating the specifics of family firms were identified in the sphere of values, organisational culture, level of social trust and hierarchy of goals. Regardless of the type of activity conducted, all family enterprises had common features which result in their identity, specific values but also problems they have to face. Not all managers emphasised the family characteristics of the company, considering that they could be received negatively. The positive and sometimes negative consequences of being a family company were pointed out. For this reason, the family characteristics of the company were not always exposed in its image.

The family character of the subject had a significant impact on the shaping of social capital. It was pointed out that with the employment of family members bound by blood ties and sharing common values and shared responsibility for the company's brand, the family name creates more trust in these people and ensures that the managers will not be cheated by them. Many years of work in the family allowed to develop a kind of 'code' that facilitates communication and easier and faster decision making both in operational matters and referring to the company's development strategy.

In the area of organisational culture, the family nature of the enterprise translated into a positive atmosphere at work through the transfer of a family atmosphere to the business ground. Employees from outside the family pointed to greater personalisation of relationships than in non-family companies in which they had previously worked. It was believed that the creation of a familial organisational culture allows the use of strengths of the family entity and to build strong ties between the company and its stakeholders.

The specificity of family enterprises was also manifested by a high level of responsibility for the family, employees and relations with the local communities in which they operate. The implementation of the long-term goal, which is the duration of the enterprise over generations, is visible in the desire to maintain and multiply assets for future generations. Therefore, it is much easier to make decisions about long-term investments and not focus on short-term profits. Despite the different valuations of familism, the respondents mostly considered familism as a factor conducive to running the enterprise. More than half regularly indicated the family nature of their business in their contacts and only one third did not underline the fact of being a family business.

An important feature of contemporary family businesses in Poland are succession processes that are implemented in many enterprises. The time that has passed since the founding of the majority of Polish family businesses causes that they will have to face the key challenge of succession soon. Only about $20 \%$ of Polish family businesses are run by 
the second or next generation of the owner family, and these results are consistent with other authors (Surdej \& Wach, 2011). These factors cause that the founders of companies start thinking about succession or are in the process of conducting a succession process. It was pointed out that the importance of succession in Polish family enterprises will grow due to the impending generational change in companies established in the period of the economic transformation in the 1990s. Most of the respondents pointed to the desire to make succession, of which $58 \%$ indicated the descendant as the successor. Unfortunately, a significant problem was the lack of succession planning and limited knowledge in this area. Only about $40 \%$ of the surveyed entities had a succession plan.

In the area of the development strategy, it was pointed out that the specialisation of the enterprise and location in the market niche were essential. The ability to perform individual and non-standard orders and high flexibility in relation to the clients' needs constitute one of the important elements of building a competitive advantage. It was also pointed out that the strategy must include correlated business goals and family goals, and the company's mission should reflect the family identity of the company. The succession plan should be the most long-term element of the strategy allowing for the preparation of a successor, but also the senior, the enterprise and the owner's family for generational change.

The results of the conducted research allowed to determine the specificity of family enterprises operating in the Polish economy and to indicate specific areas resulting from their family character and the sphere of management and social relations, including primarily the following problems:

- permanent overlapping of conflict-generating enterprise and family systems;

- planning and effectiveness of succession and the threat of a crisis accompanying the generational change;

- creation of strategic orientation and implementation of development strategies and barriers to development through the occurrence of the conflict of family goals and company goals, as well as limiting the growth of the entity;

- formation of cultural barriers resulting from familism and nepotism occurring in the organisational culture and human resource management;

- barriers in management resulting from limited knowledge of managers and limiting the participation of mercenary managers in business management.

\section{Qualitative Research 2014-2016}

Continuing the problems of the research conducted in 2009-2010, we developed the use of qualitative methods. In one of the studies carried out in the years 2014-2016 we focused on the analysis of the phenomenon of social capital in small and medium-sized family enterprises (Marjański \& Staniszewska, 2017; Sułkowski \& Marjański, 2018). We conducted qualitative research on 10 family enterprises aimed at analysing cases and comparing the results of both surveys. Among the research problems posed, we were looking for answers to the question why low social capital in Poland positively correlates with the development of small and medium family enterprises and why the high level of family social capital is a stimulus for the development of family businesses. The key method used was the indepth interview, in which we encountered the problem of getting the respondent to reflect and establish communication with the researcher in a similar way as in the previous studies. By achieving this goal, it was possible to learn about important and complex issues 
related to family social capital. The relatively small research sample and the long duration of the study also allowed the use of participant observation methods.

The research results show that a high level of social capital plays an important role in the development process of the surveyed enterprises. A well-developed dialogue between employees, as well as the care for maintaining good relationships with customers and the external environment are of great importance. The effectiveness of the surveyed enterprises was significantly influenced by the approach to employees, manifested, among others, by equal treatment of employees from outside the family as well as those from the family and the openness of managers to making new contacts and the ability to change previously defined goals. In the first place attention was paid to good performance of the task and not to who performs it. The phenomenon of the influence of familism on team development and constructive problem solving indicated in the subject literature was also confirmed.

The awareness of the family nature of the business was common among the entrepreneurs participating in the survey and family members involved in the functioning of the family enterprise. Attention was paid to the importance of commonly shared norms and values and the importance of a shared vision of the family and the enterprise. It was pointed out that the enterprise, regardless of formal provisions related to the organisational and legal form, is the joint property of the immediate family. They also pointed out that they had created their own enterprises to be able to work together with members of the immediate family. It was noticed that employees from the family, through blood ties and working on a joint account, are additionally obliged to work more effectively and also more than employees from outside the family, willing to sacrifice for the benefit of the company.

In both studies it was confirmed that a specific communication system based on a specific language code was developed, which translates into the speed and ease of decision making. On the other hand, close family relationships also allow family members to express their opinions in an easier way, less positive ones in particular. It is also important to transfer the family home atmosphere to the enterprise. Among the surveyed enterprises, there were three that were created as a reaction to previous bad work experience in non-family enterprises. One's own family business was the creation of a friendly workplace.

Building a good atmosphere and communication were influenced by the fact that people who work in the company share the same values because they come from one family or were hired because they 'fit' into its value system and organisational culture. External communication channels of small and medium family enterprises in Poland show high frequency of their use as well as flexibility and patency. As a result, companies adapt to the needs of their clients. Non-family employees indicated high personalisation of relationships and nonprofessional relations in interviews. The direct contact of the owner with the employees allowing good use of employee competences is of great importance for both parties.

Family social capital also facilitates the recovery of an enterprise from crisis situations. It was emphasised that in such situations members of the owner families undertake activities aimed at averting the crisis and limit the collection of funds from the enterprise to the absolute minimum or transfer private savings to the enterprise. In some family businesses, the problem was insufficient knowledge about the opportunities and threats resulting from the family nature of the company. It can be assumed that faster and sustainable development of family enterprises would be possible due to the implementation of effective measures aimed at understanding the importance of social capital in the process 
of managing the family business. Also, social capital is of great importance while making key decisions by family members, because it is easier to communicate with each other. Corporate matters are often discussed at family gatherings outside the company's headquarters and the lack of formalisation is considered to be a strength of the enterprises because decisions are made faster.

The conducted research confirmed the thesis that the high level of social capital based on interpersonal relations of family members is manifested by a high level of trust and cooperation and a low level of formalisation translating into more efficient and effective communication and personalisation of organisational ties (paternalism, family atmosphere). The limited size of the formalisation is also affected by the limited size of the enterprise. The smaller the entities, the smaller the formalisation, only in medium-sized enterprises detailed positioning of the hierarchy of positions, determination of responsibility, job descriptions, flow charts or communication structure begin to appear, often caused by external factors, e.g. the need to introduce in the company standards that are required by large business partners.

The family nature of a company also translates into long-term business goals and ensuring stable growth in the long-term and greater adaptability of the company to changing environmental conditions. The key sources of high family capital were trust, common pursuit of the defined goal and greater involvement in the development of the family entity. It turns out that blood ties, sharing common values, co-responsibility for the surname, brand of the company cause that thanks to this the founders of companies are sure that they can count on the employees from the family.

The analysis of the results of the presented research shows great trust among family members, but on the other hand, it confirms the thesis about the crisis of social capital among the Poles - clearly indicating the deficit of social trust in relation to representatives of other social groups. The research shows that the level of trust in family businesses is directly proportional to the degree of family intimacy. The owners declare total trust in relation to people from the closest family circle and employees from the family are considered to be completely loyal and committed. This means that they are entrusted with key, responsible positions in the company in the belief that they will care for the brand of the family business. It should be recognized that the trust that family members endure is the foundation of a family business and is often the main bond of social capital. For this reason, the family was often referred to as a 'clan' - with all positive and negative consequences: very much trust in each other, distrust of people from outside the clan.

On the one hand, common values favour the development of family members and the company they run, but on the other hand, family members are obliged to work more effectively and make greater sacrifices for the company. The business owner knows all the strengths and weaknesses of the family worker and thanks to that he is able to manage it better and assign his employees tasks that will allow him to use their potential fully, as well as not require tasks in which the person is not good at or does not like to perform. It is worth noting that employees from the family show greater willingness to work outside the standard working hours and if necessary, they can take on all positions, even the lowest ones. Greater dedication to work also results from the financial responsibility that family members bear as an enterprise, as well as care for the material existence of the family. 
Greater motivation to work and responsibility of family members is identified both by owners, managers, but also by employees from outside the family.

The analysis of the results of research on the positive impact of low social capital on development in small and medium-sized family enterprises in Poland allows for the following conclusions:

- the deficit of social capital in interpersonal relations and authorities encourages to undertake economic activity based on the primary community, that is the family;

- in small and medium-sized family enterprises the family is a source of social capital, which takes on a specific form of social capital of the family;

- small and medium-sized family enterprises rely on the interdependence of business and the owner's family and use a high level of trust for family members, and through strong and frequent personal interactions generate a special form of social capital that can be a source of their competitive advantage;

- there is reluctance in small family enterprises to formalise and coordinate cooperation in the entity;

- on the level of social capital of the surveyed family enterprises, the impact of commonly shared norms and family values is manifested;

- a high level of family social capital has a significant impact on the development of small and medium family enterprises.

It can be pointed out that the nature of social capital of small and medium family enterprises in Poland is of great importance for the family to achieve success together with the limitation of manifesting family emotions in the enterprise. Integration, common value system, trust and knowledge sharing are the result of a high level of social capital in the surveyed enterprises.

\section{Qualitative Research 2017-2018}

Another study on the strategic orientation in family enterprises was carried out in the period of 2017-2018 (Marjański et al., 2018). A qualitative approach was selected because it allows to reach specific cases and creates the opportunity to learn about the specifics of the surveyed enterprises (Toften \& Hammervoll, 2010). The research sample consisted of 20 companies in which in-depth interviews were conducted based on a repetitive research scenario, which included the opportunity to ask interlocutors additional questions to further specify the issues raised. The interview scenario was consulted with three external experts. Interviews were conducted in family enterprises operating in the Lodz region.

Small and medium-sized enterprises, which declared themselves as family enterprises and met the conditions resulting from the adopted definition of a family enterprise understood as an economic organisation based on family ties and relationships, which seeks to sustainably maintain a decisive influence on the family business through participation in the future ownership, management and responsibility with the intention to transfer it to the next generation, were selected for the research.

The main research goal was to identify the specifics of strategic orientation in family enterprises by getting answers to some basic questions: do surveyed family enterprises have strategic orientation, and if so, is it superior to the strategy, or how familistic features influence strategic orientation and what significance in the strategic orientation has the opportunity to use development support instruments offered by business environment institutions. 
The conducted research showed that obtaining data about strategic orientation was not easy. In the surveyed family enterprises, the common reluctance to reveal key information for the development of the company to researchers was confirmed. This situation is related to the overlap of the enterprise and family system, which means that the disclosure of business factors was related to the need to disclose information related to the family. Another problem that occurred in the research were terminological issues related to the ambiguous understanding of the terms: strategic orientation, strategy or development process.

The surveyed companies have strategic orientation, but in most cases they could not name it. In 14 entities, strategic orientation was superior to the strategy, and in the remaining entities the respondents were not able to take a position. In all enterprises, the impact of familism on the shaping of strategic orientation was pointed out, as well as the fact that the family nature of business is an important strategic factor increasing the opportunities for success in the dimension of the enterprise and the owner's family. It was pointed out that thanks to the family nature of the business, valuable and rare human resources are gaining, based on trust in the family social capital, as well as valuable material and financial resources. Familistic features also affect the easier development of knowledge resources and care for the company's reputation.

An important issue was to determine what role is played by strategic orientation in the development process of the surveyed enterprises. The respondents indicated that it is a guideline to undertake entrepreneurial activities as well as to seek and use market opportunities. The shape of strategic orientation translated into building a competitive advantage, which assumes operating in a niche market and innovation. It was pointed out that such an approach allows the development of the entity as well as the effectiveness of its functioning. The importance of the environment in which enterprises operate and the availability of financial and material resources was also pointed out. It was felt that it was necessary to ensure the development of the company by introducing new technological and organisational solutions in order to maintain its competitiveness and the possibility of transferring the company to the next generation in good condition. Entrepreneurs pointed out that in the process of enterprise development acquiring external sources of financing, especially non-returnable ones, is of crucial importance. In the enterprises surveyed, the strategic orientation was focused on the development of the company measured by qualitative changes such as: an increase in profitability, an increase in the value of product sales and the introduction of innovative technologies, as well as ensuring business continuity and conducting the succession process.

Since only family enterprises operating in rural areas were included in the research sample, the research results should be treated as a preliminary proposal requiring the extension of research to adopt a more utilitarian perspective allowing the most in-depth analysis and description of factors determining the strategic orientation of family enterprises.

\section{CONCLUSIONS}

The contemporary Polish economy is characterised by high dynamics of changes in operating conditions and diversity of entities functioning in it but Poland can be considered a country where family businesses are and will be the dominant form of running a business. One of the many advantages of family entrepreneurship is that it is not based only on economic indica- 
tors, but also on a long-term development strategy and people are the most important capital of every family company. Entrepreneurship in family businesses in Poland is characterised by the specificity resulting from focusing primarily on the personal, material and financial resources of the family. On the other hand, the number of successions is growing.

Most family businesses that managed to survive the initial stage of activity are wellorganised entities, aware of the family nature of the business and the emerging tradition of the company, often producing goods and services of the highest quality. Entrepreneurs of family businesses have mastered the strategy of finding market niches that 'giants' of economic activity do not penetrate. At present, family enterprises in Poland play a very important role on both the macro and micro scale. Family enterprises create the largest number of jobs, almost half of GDP and are a source of competition and development of the market mechanism. They are also able to compete with enterprises from the most developed countries. They have also proved that they are able to cope with globalisation processes in an increasingly integrating global economy.

Looking from the perspective of the transformation processes that took place in Poland, the development of family entrepreneurship is one of the most important successes. Family businesses are an expression of the entrepreneurship of the Poles and their families who took the risk of starting their own business. Many of these enterprises have achieved market and social success. Although the majority of Polish family enterprises operate on local markets, there are more and more often those that enter the path of internationalisation and successfully compete on global markets.

The functioning of family entrepreneurship in Poland is subject to constant evolution. The occurring changes result both from internal factors related to the life cycle of the company and family and succession processes, as well as from changes taking place in their environment resulting also from participation in the common European market and the internationalisation of operations. Enterprises which, thanks to their development strategy, have achieved success, build their own brand and improve management methods, introduce innovations and change their market behaviour. They also face many challenges related to family management as well as planning and conducting succession.

\section{REFERENCES}

Aldrich, H.E., \& Ruef, M. (2006). Organizations Evolving. London: Sage.

Astrachan, J. (2003). Commentary on the special issue: The emergence of a field. Journal of Business Venturing, 18(5), 567-572.

Astrachan, J.H., \& Shanker, M.C. (2003). Family Businesses Contribution to the US Economy: a Closer Look. Family Business Review, 16(3), 211-219.

Barney, J. (1991). Firm resources and sustained competitive advantage. Journal of Management, $17(1), 99-120$.

Bednarz, J., Bieliński, T., Nikodemska-Wołowik, A.M., \& Otukoya, A. (2017). Sources of the Competitive Advantage of Family Enterprises: An International Approach Focusing on China, Nigeria and Poland. Entrepreneurial Business and Economics Review, 5(2), 123-142. https://doi.org/10.15678/EBER.2017.050207

Bilan, Y., Lyeonov, S., Vasylieva, T., \& Samusevych, Y. (2018). Does tax competition for capital define entrepreneurship trends in Eastern Europe?. On-line Journal Modelling the New Europe, (27), 34-66. 
Binz-Astrachan, C., Botero, I.C., Astrachan, J.H., \& Prügl, R. (2018). Branding the family firm: a review of foundations, current knowledge, and avenues for further research. Journal of Family Business Strategy, 9(1), 1-13. https://doi.org/10.1016/j.jfbs.2018.01.002

Bird, B., Welsch, H., Astrachan, J.H., \& Pistrui, D. (2002). Family business research: The evolution of an academic field. Family Business Review, 15(4), 337-350.

Chrisman J.J, Chua J.H., \& Steier, L.P. (2003), An Introduction to Theories of Family Business. Journal of Business Venturing, 18, 441-448.

Chrisman, J.J., Chua, J.H, \& Sharma, P. (2003a). Current trends and future directions in family business management studies: Toward a theory of the family firm. Coleman White Paper Series, no 41.

Cristiano E. (2017). Specific Features of Family Businesses: A Contribution to Literature. In M. Bilgin, H. Danis, E. Demir, \& U. Can (Eds.), Financial Environment and Business Development (Eurasian Studies in Business and Economics, 4. Cham: Springer.

Czapiński, J., \& Panek, T. (Eds.) (2011). Social diagnosis 2011. Objective and subjective quality of life in Poland. Contemporary Economics, 5(3), 14-61.

Gasson, R., Crow, W., Errington, A., Hutson, J., Marsden, T., \& Winter, D. (1988). The farm as a family business. A Review. Journal of Agricultural Economics, 36, 1-41.

Gómez-Mejía. L.R., Haynes, K.T., Núñez-Nickel, M., Jacobson, K.J.L., \& Moyano-Fuentes, J. (2007). Socioemotional wealth and business risks in family controlled firms: Evidence from Spanish olive oil mills. Administrative Science Quarterly, 52(1), 106-137.

Hadryś-Nowak, A. (2018). Family Entrepreneurship Orientation in Family Owned SMEs: A Key Resource for Internationalization?. Entrepreneurial Business and Economics Review, 6(2), 153-169. https://doi.org/10.15678/EBER.2018.060208

Handler, W.C. (1989). Methodological issues and considerations in studying family businesses. Family Business Review, 2(3), 257-276.

Harris, R., Martinez, J., \& Ward, J. (1994). Is strategy different for the family-owned business?. Family Business Review, 7(2), 159-174.

Hoy, F. (2014). Entrepreneurial Venturing for Family Business Research. In L. Melin, M. Nordqvist, \& P. Sharma (Eds.), The Sage Handbook of Family Business (pp. 620-628). Los Angeles: Sage.

Ibrahim, N.A., Angelidis, J.P., \& Parsa, F. (2008), Strategic management of family businesses: current findings and directions for future research. International Journal of Management, 25(1), 95-110.

IFERA. (2003). International Family Enterprise Research Academy (Family businesses dominate. Family Business Review, 16(4), 235-240. https://doi.org/10.1177/08944865030160040201

Ivanová, E. (2017). Barriers to the development of SMEs in the Slovak Republic. Oeconomia Copernicana, 8(2), 255-272. https://doi.org/10.24136/oc.v8i2.16

Jeżak, J. (2014). Przedsiębiorczość rodzinna na świecie - rola i znaczenia oraz cechy specyficzne. In J. Jeżak (Ed.), Przedsiębiorstwa rodzinne w Polsce. Łódź: Wydawnictwo Uniwersytetu Łódzkiego.

Korcsmáros, E., \& Šimova, M. (2018). Factors affecting the business environment of SMEs in Nitra region in Slovakia. Oeconomia Copernicana, 9(2), 309-331. https://doi.org/10.24136/oc.2018.016.

Kot, S., Meyer, N., \& Broniszewska, A. (2016), A Cross-Country Comparison of the Characteristics of Polish and South African Women Entrepreneurs. Economics and Sociology, 9(4), 207-221. https://doi.org/10.14254/2071-789X.2016/9-4/13

Lansberg, I. (1983). Managing Human Resources in Family Firms: The Problem of Institutional Overlap. Organizational Dynamics, 12(1), 39-49.

Leszczewska, K. (2017). The concept of the business model of the family businesses. Research on Enterprise in Modern Economy - Theory and Practice, 3(22), 125-136. 
Lumpkin, G.T., \& Brigham, K.H. (2011). Long-term orientation and intertemporal choice in family firms. Entrepreneurship Theory and Practice, 35(6), 1149-1169. https://doi.org/10.1111/j.15406520.2011.00495.x

Marjański, A., \& Staniszewska, K. (2017). Kapitał społeczny rodziny jako źródło stymulacji tworzenia i rozwoju małych i średnich przedsiębiorstw rodzinnych w Polsce. Przedsiębiorczość $i$ Zarzqdzanie, XV (7[1]), 197-209.

Marjański, A., Staniszewska, K., \& Marjańska-Potakowska, J. (2018). Zrozumienie specyfiki małych i średnich przedsiębiorstw rodzinnych jako źródło synergii w relacjach z administracją publiczną. Przedsiębiorczość i Zarzqdzanie, XIX(7[1]), 275-287.

McMillan, J., \& Woodruff, Ch. (2003). The central role of entrepreneurs in transition economies. In G.S. Fields \& G. Pfeffermann (Eds.), Pathways Out of Poverty (pp. 105-121). Dordrech: Springer. https://doi.org/10.1007/978-94-010-0009-3_6

Miller, D., \& Le Breton-Miller, I. (2006). The best of both worlds: Exploitation and exploration in successful family businesses. Advances in Strategic Management, 23, 215-240.

Ministry of Industry and Trade in Poland. (1995). Małe i średnie przedsiębiorstwa w gospodarce narodowej. Warszawa: Ministerstwo Przemysłu i Handlu.

Moss, T.W., Payne, G.T., \& Moore, C.B. (2014). Strategic Consistency of Exploration and Exploitation in Family Businesses. Family Business Review, 27(1), 51-71.

Nowak, S. (1981). Values and attitudes of the Polish people. Scientific American, 245, 45-53.

PARP. (2014). Report on the condition of small and medium-sized enterprise sector in Polnad in 2012-2013. Warszaw: Polish Agency for Enterprise Development.

Petrů, N., \& Havlíček, K. (2017). Family entrepreneurship in the Czech Republic on the verge of first generation handover. Journal of International Studies, 10(4), 119-130. https://doi.org/10.14254/2071-8330.2017/10-4/9

Rogalska, E. (2018). Multiple-criteria analysis of regional entrepreneurship conditions in Poland. Equilibrium. Quarterly Journal of Economics and Economic Policy, 13(4), 707-723. https://doi.org/10.24136/eq.2018.034

Safin, K. (2014). Strategie i praktyki sukcesyjne polskich przedsiębiorstw rodzinnych. Prace Naukowe Uniwersytetu Ekonomicznego we Wrocławiu, 366, 449-459.

Sharma, P. (2004). An overview of the field of family business studies: current status and directions for the future. Family Business Review, 17(1), 1-36.

Sharma, P., Christman, J.J., \& Gersick, K.E. (2012). 25 Years of Family Business Review: Reflection on the Past and Perspectives for the Future. Family Business Review, 25(1), 5-15.

Sharma, P., Melin, L., \& Nodqvist, M. (2014). Scope, Evolution and Future of Family Business Studies. In L. Melin, M. Nordqvist \& P. Sharma (Eds.), The Sage Handbook of Family Business. Los Angeles: Sage.

Simon, H. (2009). Hidden Champions of the 21st Century. New York: Springer.

Sirmon, D.G., \& Hitt, M.A. (2003). Managing resources: Linking unique resources, management, and health creation in family firms. Entrepreneurship: Theory and Practice, 27(4), 339-358.

Sułkowski, Ł., Marjański, A., Kowalewska, A., Lewandowska, B., Kwiatkowska, M., \& Krynicki, T.J. (2009). Family Businesses and the Polish Economy - Opportunities and Challenges. Warszawa: Polish Agency for Enterprise Development.

Sułkowski, Ł., \& Marjański, A. (2011). Specific nature of Polish small and medium-sized family businesses - conclusion from empirical studies, In A.Z. Nowak, B. Glinka \& P. Hensel (Eds.), Competition Ethics Management (pp. 147-167). Warsaw: University of Warsaw. 
Sułkowski, Ł., \& Marjański, A. (2014). Metodyka badań firm rodzinnych. Przedsiębiorczość i Zarzqdzanie, XV(7-I), 11-21.

Sułkowski, Ł., \& Marjański, A. (2014a). Metodyka badań jakościowych w małych podmiotach rodzinnych. Problemy Zarzq̨dzania, 12(3[47]), 222-23, https://doi/10.71772/1644-9584.47.12

Sułkowski, Ł., \& Marjański, A. (2015). Polish small and medium-sized family businesses - trajectories of success. Management \& Gouvernance, 13, 75-94.

Sułkowski, Ł., \& Marjański, A. (2018). Duo-ethnography as the Qualitative Inquiry in Small Family Business Research. Management, 22(2), 95-109. https://doi/10.2478/manment-2018-0025

Surdej, A., \& Wach, K. (2011). Succession Choices in Family Businesses: The Case of Poland. Toruń: Wydawnictwo Adam Marszałek.

Szaban, J., \& Skrzek-Lubasińska, M. (2018). Self-employment and entrepreneurship: A theoretical approach. Journal of Management and Business Administration. Central Europe, 26(2), 89-120.

Sztompka, P. (1998), The cultural imponderables of rapid social change: trust, loyalty, solidarity. Polish Sociological Review, 121, 45-56.

Toften, K., \& Hammervoll, T. (2010). Strategic orientation of niche firms. Journal of Research in Marketing and Entrepreneurship, 12(2), 108-121.

Ubrežiová, I., Wach, K., \& Horváthová, J. (2018). Entrepreneurship in small and medium-sized enterprises: Comparative study between Slovakia and Poland for the years 2001-2007. Agricultural Economics, 54(8), 358-366.

Wach, K. (2015). Środowisko biznesu rodzinnego jako symulanta intencji przedsiębiorczych młodzieży akademickiej. Przedsiębiorczość i Zarzqdzanie, XVI(7), 25-40.

Wach, K. (2017). Exploring the Role of Ownership in International Entrepreneurship: How does Ownership Affect Internationalisation of Polish Firms?. Entrepreneurial Business and Economics Review, 5(4), 205-224. https://doi/10.15678/EBER.2017.050410

Więcek-Janka, E., Contreras Loera, M.R., Kijewska, J., \& Tirado, G. (2016). Competencies' model in the succession process of family firms with the use of grey clustering analysis. ZN Politechniki Poznańskiej Organizacja i Zarzqdzanie, 70, 215-226, https://doi/10.21008/j.0239-9415.2016.070.16

Wilson, S.R., Whitmoyer, J.G., Pieper, T.M., Astrahan, J.H., Hair, J.F. Jr., \& Sarstedt, M. (2014). Method Trends and Method needs: Examining Methods Needed for Accelerating, the Field. Journal of Family Business Strategy, 5, 4-14.

Zygmunt, J. (2018). Entrepreneurial activity drivers in the transition economies. Evidence from the Visegrad countries. Equilibrium. Quarterly Journal of Economics and Economic Policy, 13(1), 89103. https://doi.org/10.24136/eq.2018.005 


\section{Authors}

The contribution share of authors is equal and amounted to $50 \%$ each of them.

\section{Andrzej Marjański}

Deputy Dean of the Faculty of Management, head of the Department of Entrepreneurship and Family Businesses at the University of Social Sciences in Łódź. His research interests and activity as an expert concentrate on the issues of family enterprises, development strategies, entrepreneurship and management of small and medium-sized enterprises. He has participated in several research projects and worked as an expert in the committees for the evaluation of economic projects. Since 2011, he has been chairing the Family Businesses scientific conference, organised by the Entrepreneurship and Family Businesses Institute of the University of Social Sciences in Łódź. He was the scientific coordinator in the Pentor research project for the Polish Agency for Enterprise Development and the vice-chairman of the Program Council and an expert in the PARPIFR Family Business Training and Consulting Project.

Correspondence to: Dr Andrzej Marjański, University of Social Sciences in Łódź, Faculty of Management, Department of Entrepreneurship and Family Businesses, ul. Sienkiewicza 9, 90-113 Łódź, Poland, e-mail: amarjanski@san.edu.pl

ORCID (i) http://orcid.org/0000-0001-6534-2632

\section{Łukasz Sułkowski}

Full professor of economic sciences and holds a PhD in Humanities. His research interests include organisation and management, and in particular: critical management studies, epistemology and methodology of social sciences and the humanities, organisational culture and intercultural management, public management and management of family businesses. Currently a professor at the Faculty of Management and Social Communication of the Jagiellonian University, at Clark University and the Chair of the Management Department at the University of Social Sciences in Łódź, Poland. A member of the Presidium of the Polish Accreditation Committee since 2012. Since 2008 - the Editor-in-chief of the quarterly 'Journal of Intercultural Management', in 2004-2011 the editor-in-chief of the quarterly 'Organization and Management'.

Correspondence to: Prof. dr hab. Łukasz Sułkowski, University of Social Sciences in Łódź, Faculty of Management, Department of Management, ul. Sienkiewicza 9, 90-113 Łódź, Poland, e-mail: Isulkowski@san.edu.pl

ORCID (1) http://orcid.org/0000-0002-1248-2743

\section{Copyright and License}

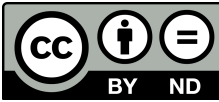

This article is published under the terms of the Creative Commons Attribution - NoDerivs (CC BY-ND 4.0) License http://creativecommons.org/licenses/by-nd/4.0/

Published by the Centre for Strategic and International Entrepreneurship - Krakow, Poland 